\title{
No una sino muchas repúblicas: una aproximación a las bases teóricas del republicanismo peruano, 1821-1834
}

\author{
por \\ Carmen McEvoy \\ Universidad de South, Sewanee
}

El articulo se propone explorar tres de las vertientes del republicanismo peruano entre 1821 y 1834. La primera, la "patria científica» que floreció en el seno de la Sociedad Patriótica de Lima y está representada por un grupo de hombres de ciencia liderados por Hipólito Unanue, entre los que destacó José Gregorio Paredes. La segunda vertiente, de corte jurídico-filosófico por su énfasis en conceptos como los de libertad y soberanía, se irá gestando en la discusión entre la opción de una monarquía constitucional y otra de carácter estrictamente republicano, siendo su vocero el abogado trujillano José Faustino Sánchez Carrión. El republicanismo militarizado, que es la última categoría que se discute en este trabajo, surge como una respuesta al problema de la guerra contra el imperio español y es construida por "soldados de la República» como Domingo Nieto.

Palabras clave: Perú; independencia; cultura política; republicanismo; patria científica; republicanismo militarizado.

\section{INTRODUCCIÓN}

«He tomado las medidas más enérgicas para mantener el orden, defender el departamento de todo ataque y salvar, si es posible, a la República», le escribió el general Domingo Nieto al presidente Luis José de Orbegoso el 14 de enero de 1834. En la misiva, el militar no solo reiteró su compromiso con la causa liberal, encabezada por la Convención Nacional, sino que prometió derramar

1 Este artículo forma parte del Proyecto I+D, Tiempos de desconcierto. Política y sociedad en la Independencia del Perú, 1820-1824, Referencia HAR2008-03259, financiado por el Ministerio de Ciencia e Innovación de España. 
«la última gota de su sangre por la legalidad» de la patria en peligro ${ }^{2}$. Luego de la derrota de la asonada militar en contra de Orbegoso de inicios de 1834, dicho general recibió una serie de cartas con motivo de su elección como jefe de Estado, ocurrida en diciembre de 1833. La lectura de ellas permite entender la importancia del apoyo brindado por Nieto a la causa de la libertad y también evaluar lo que los corresponsales esperaban del nuevo gobernante. El uso de categorías familiares para referirse al presidente electo por la Convención alude a una interpretación del poder político en términos estrictamente morales. Al ser el jefe de Estado «el padre de la República», su deber era manejar las cosas con el mayor tino para luego «castigar a los delincuentes y salvar al inocente». Dentro de ese contexto, el político liberteño era el «juez incorruptible» que el cielo había enviado para distribuir dones entre los peruanos. En una república cuyo mayor blasón era el respeto por las garantías, no era justo - señalaba un «patriota benemérito»- que se le despojase de su más sagrada posesión. A lo que se refería el veterano de Ayacucho era al puesto público que - en sus palabras - lo protegía a él y a su familia de la mendicidad. La voluminosa correspondencia del presidente muestra que, además de enfrentar una guerra interna y otra externa, su administración debió lidiar con un desafío de dimensiones colosales. Este consistía en demostrar, de manera concreta, que el poder servía a los fines del bien común y que, por ello, quien lo detentara estaba obligado a promover la felicidad de toda la república ${ }^{3}$.

A la dimensión utópica del pensamiento republicano se refirió, en su momento, José Faustino Sánchez Carrión cuando afirmó que al declararse independiente el Perú no se propuso tan solo el acto político de romper con la que fue su metrópoli, sino la búsqueda del bienestar material que sus ciudadanos creían merecer ${ }^{4}$. El editorialista de La Abeja Republicana y futuro presidente del Primer Congreso Constituyente asoció su particular visión de la «utopía republicana» a la poderosa imagen de las calles peruanas «empedradas con oro y plata ${ }^{5}$. La participación en las guerras de la independencia fue uno de los argumentos de los que pretendieron los dones de la república del bienestar convocada por Sánchez Carrión en su conocida carta. «Espero de vuestra excelencia el justo premio [...] —en medio de catorce años de largas tareas y fati-

2 Para esta discusión, ver carta de Domingo Nieto a Luis José de Orbegoso, 14 de enero de 1834, y proclama de Arequipa en McEvoy, 2011 b.

3 McEvoy, 2010, 1: 27-81.

4 Para un análisis del discurso en la prensa en la independencia del Perú, Martínez Riaza, 1985.

5 «Carta al editor del Correo Mercantil, Politico y Literario sobre el gobierno monárquico del Perú», en La Abeja Republicana, jueves 15 de agosto de 1822. 
gas en obsequio y servicio de la madre patria-», señaló desde Chincha el veterano Vicente Toledo. Militares desmovilizados y empobrecidos solicitaron al presidente Orbegoso lo que estuviera disponible, aunque ello fuera un «destino» en algún pueblito alejado de la serranía peruana. La recompensa por los servicios prestados al Perú llegó a cientos de militares que, como Domingo Nieto, participaron en innumerables combates por la independencia nacional. Los puestos en la recién inaugurada administración pública fueron, asimismo, a manos de un importante número de civiles que volcaron su conocimiento a la causa del progreso. Así, en medio de la guerra civil que modeló la cultura política peruana, es posible observar la presencia de otros actores políticos que, pese a su debilidad frente al poder militar, procuraron inventar una república anclada en un Estado eficiente. Es el caso del funcionario Esteban de Alzaga, administrador de la tenencia de Piura, quien envió a Orbegoso un elaborado informe sobre su labor burocrática en dicha localidad. En su extensa carta, Alzaga subrayó que su objetivo fundamental era salvaguardar «los intereses del Estado» peruano ${ }^{6}$.

La república fue un espacio donde podían concretarse los sueños de adelanto material y de orden, pero ella fue también percibida como la cuna de la libertad, de la dignidad y del honor. Por un lado, es posible identificar los intentos de construir un Estado, y por el otro, los deseos de forjar una nación desde la sociedad civil. Dentro de ese contexto, el proyecto monárquico de Bernardo Monteagudo, asesor político del general José de San Martín, fue confrontado por los republicanos peruanos, quienes utilizaron la prensa para defender su posición política e ideológica. Su argumento central fue que las discusiones que afectaban al país no podían hacerse a puerta cerrada, y por ello cualquier decisión sobre el futuro del Perú debía contar con la aprobación de la ciudadanía. Un análisis de la «Carta sobre la inadaptabilidad del gobierno monárquico» de Sánchez Carrión permite acercarse a un republicanismo que madura en medio de la guerra. Por introducir nuevos argumentos y una estrategia política exitosa, la carta expresa el lenguaje secular de la revolución política y cultural que la independencia trajo a la superficie. Desarrollado a lo largo de varios años de enfrentamiento soterrado contra el autoritarismo del virrey José Fernando de Abascal, en dicho lenguaje los descontentos, las aspiraciones y las tradiciones culturales serán expresadas mediante un vocabulario simple y elocuente. A este respecto, Víctor Peralta ha introducido elementos innovadores para el análisis con sus propuestas sobre la influencia que tuvo el liberalismo hispano en la modernización de la cultura política del Virreinato ${ }^{7}$.

\footnotetext{
6 McEvoy, 2010, 1: 27-81.

7 Peralta, 2010.
} 
La posibilidad que tuvieron los republicanos peruanos de hegemonizar la esfera pública y de diseminar una serie de conceptos, siendo el más importante el de la libertad, estuvo estrechamente unida al declive de la nobleza colonial, que fue seriamente golpeada por la política económica del gobierno protectoral encabezado por San Martín ${ }^{8}$. Es importante advertir que algunos de sus colaboradores, como fue el caso de José Gregorio Paredes, expresaron en la Sociedad Patriótica de Lima una visión de una república, científica y ordenada, que ellos también anhelaban para el Perú.

Este artículo tiene por finalidad explorar tres de las vertientes del republicanismo peruano entre 1821 y 1834. La primera, que denominamos la «patria científica», florece en el seno de la Sociedad Patriótica de Lima y está representada por un grupo de hombres de ciencia que, como José Gregorio Paredes, fueron consolidándose como parte de la bancada congresal organizada bajo la égida de Hipólito Unanue. La segunda vertiente, de corte jurídico-filosófico por su énfasis en conceptos como los de libertad y soberanía, se irá gestando en la discusión entre la opción de una monarquía constitucional y otra de carácter estrictamente republicano. Su vocero es el abogado trujillano José Faustino Sánchez Carrión. El republicanismo militarizado, que es el último concepto que se discutirá en este trabajo, surge como una respuesta al problema de la guerra contra el imperio español. La noción de la república en armas trasciende, sin embargo, el tema del conflicto militar — que, como bien sabemos, recae en su última fase en manos de Simón Bolívar - para imbricarse con el del ciudadano armado y, además, con el de la anarquía, que solo el ejército puede, en teoría, neutralizar. Así, este último se erigirá como el guardián del orden y del bienestar de la república. La parte final de este artículo brinda luces sobre la revolución constitucionalista liderada por el general Domingo Nieto. Es este evento histórico, desarrollado en el verano de 1834, el que muestra en toda su profundidad el modelo de república militarizada que, opinamos, forma parte de la tradición política del Perú decimonónico. Antes de pasar a analizar estas tres «cepas republicanas» — que, obviamente, no son químicamente puras porque incluso se superponen - , es importante aclarar algunos conceptos relacionados al republicanismo y al liberalismo en general y a su manifestación en el territorio del ex Virreinato español.

\footnotetext{
8 McEvoy, 2002: 34-63.
} 
FORJANDO LA REPÚBLICA

Antonio José de Irisarri, ese incansable y díscolo guatemalteco de nacimiento, luchador por la independencia de Chile e intendente en ese país, escribió en 1828: «Creemos que no hay más que decir república para decir felicidad», para a renglón seguido añadir: «La astucia de algunos individuos sobre la falta de ilustración de la masa popular, ha sido siempre el escollo en que perecen las repúblicas. El pueblo, entusiasmado por la libertad, tal vez trabaja por destruirla». El texto de Irisarri refleja con meridiana claridad la tensión en esa república querida y temida, entre el amor a la libertad y a la razón y el miedo al caos y a la anarquía que comparten los primeros políticos del siglo XIX hispanoamericano9 ${ }^{9}$ Sin embargo, el recelo frente a la carencia de aquello que Sánchez Carrión denominó como «la aptitud civil de la república» cedió ante la certidumbre de que la instauración de un orden republicano era la única alternativa viable luego del derrumbe del sistema colonial. Fue por esa «porfiada insistencia» a favor de una fórmula política frente a la cual Europa empezaba a mostrar una profunda desconfianza que Hispanoamérica se convirtió en «un campo de experimentación formidable», donde ideas e instituciones originadas en el Viejo Mundo fueron adoptadas y adaptadas, al mismo tiempo que se generaban y ensayaban prácticas políticas nuevas, diversas, de resultados inciertos ${ }^{10}$.

El establecimiento de «buenos gobiernos republicanos», capaces de resolver el urgente problema de la representación política, se convirtió en una tarea titánica en el Perú. El congresista Francisco Xavier de Luna Pizarro opinaba que la «sublime empresa» de «constituir una república» era un desafío tremendo debido a lo «forzoso» que era «acordar opiniones» en un mundo caracterizado por la heterogeneidad. El sacrificio del bien individual «en aras del verdadero bien nacional» — ineludible deber de todo buen republicano- irremediablemente colisionaba contra el «desastroso principio del interés personal» ${ }^{11}$. Trabajos como el de José Carlos Chiaramonte nos han hecho reflexionar respecto de los olvidos que fueron necesarios para construir ese «mito de una nacionalidad originaria» íntimamente ligado al proyecto republicano de corte unitario como el propuesto por Luna Pizarro ${ }^{12}$. Dentro de una línea de argumentación que cuestiona la preeminencia de una identidad nacional temprana pero que reconoce la presencia de una fuerte conciencia americanista, la

\footnotetext{
9 El Semanario Republicano, 1818.

10 Sábato, 2006.

11 Luna Pizarro, 1959.

12 Chiaramonte, 2004.
} 
clave para entender la cartografía político-cultural del siglo XIX radica en una aproximación al vocabulario y a las prácticas de sus principales actores.

La atención al republicanismo como problema conceptual de profundas implicaciones para la comprensión de la cultura política en Hispanoamérica ha sido puesta en el tapete de su historiografía junto con el rescate de la historia de las ideas y del pensamiento político ${ }^{13}$. El desarrollo anterior, estrechamente asociado a la revaloración del tema de la ciudadanía, tiene que ver con la madurez de la disciplina histórica, cuyo mayor logro ha consistido en desplazarse de los estrechos márgenes a los cuales la tenía reducida el materialismo histórico y sus derivados ideológicos. La recuperación de la vieja discusión en torno a la construcción del poder, una verdadera revolución copernicana mediante la cual se ha logrado incorporar la complejidad de sus procesos, prácticas y símbolos en el contexto de un intenso quehacer ideológico, no excluye el análisis de la praxis política. Por otro lado, la vuelta a la biografía ha posibilitado tomar en consideración el papel de los actores individuales, lo que ha permitido una ampliación del ámbito de la tradicional historia política, aunque sin descuidar a la historia social con sus redes de personas e ideas; estas últimas fundamentales para entender la trama en la que se fue gestando la política hispanoamericana ${ }^{14}$.

Corriendo el riesgo que tienen todas las filiaciones estrictas, no está de más recordar que la Universidad de Cambridge en Inglaterra fue relevante en reposicionar la historia intelectual con su serie Ideas in Context y cien títulos publicados en historia del pensamiento político. Quentin Skinner, desde esas aulas, dio un empuje especial a esta área de estudios al defender la lectura de los textos clásicos como productos de su contexto histórico y no tanto como repositorios eternos de una sabiduría superior. El espacio intelectual y lingüístico en el cual surge el texto es tan fundamental que se hace imposible comprender los matices del pensamiento que quiso formular su autor si no se explora la situación dentro de la cual este se hace inteligible. El estudio de J.G.A. Pocock sobre Maquiavelo, publicado en 1975, infundió nuevos bríos al tema del republicanismo clásico o «neorromano», el cual allanó el camino a toda una línea revisionista de la historia de dicho concepto, tanto en Estados Unidos como en Hispanoamérica ${ }^{15}$.

A la tradicional filiación del republicanismo americano con la Revolución Francesa y los «idéologues» de la Ilustración, se ha agregado el legado de la «tradición atlántica», que habría llegado a América traspasando las fronteras

13 Palti, 2007.

14 Esta discusión en McEvoy y Stuven, 2007: 13-35.

15 Pocock, 1975; 1985. Skinner, 1988; 1997; 2002. 
mentales y temporales de la Roma antigua hacia las repúblicas italianas y, atravesando posteriormente el océano Atlántico, hacia Estados Unidos. La visión de Skinner, Pocock y otros restauradores de la historia conceptual, como Manfred Koselleck, ha permitido, por lo tanto, que el republicanismo clásico del Renacimiento italiano pudiese vincularse con las revoluciones de Inglaterra en el siglo XVII, de Norteamérica en el XVIII o de Hispanoamérica en el XIX. The Machiavellian Moment, de Pocock, cuyo título fue sugerido por Skinner, sostuvo que el «republicanismo clásico» de Maquiavelo, con su énfasis en el equilibrio de poderes, el régimen mixto, la virtud cívica y una ciudadanía en armas, habría inspirado al filósofo inglés James Harrington en la elaboración de su utopía The Commonwealth of Oceana de 1656, y en sus postulados antiabsolutistas durante la Guerra Civil inglesa, para posteriormente dar forma a un «humanismo cívico». Este humanismo fue identificado en la década de 1960 por los historiadores estadounidenses Gordon Wood y Bernard Bailyn en el discurso sobre bien común, anticorrupción y ciudadanía virtuosa predominante entre los padres de la patria norteamericanos ${ }^{16}$. Como lo explicó también Pocock, el republicanismo clásico hizo de la virtud cívica — la capacidad de anteponer el bien de la comunidad al propio - la piedra de tope de la estabilidad constitucional y el orden que posibilitaba la libertad. En realidad, en este aspecto fue determinante la desconfianza maquiavélica en las minorías y la necesidad de contener su ambición.

El tema de la relación entre republicanismo clásico y el pensamiento político de los intelectuales de los territorios americanos ha producido una gran cantidad de literatura, a pesar de que su importancia ha sido considerada exagerada por algunos historiadores, como Joyce Appelby. Según esta autora, el retorno al tema del republicanismo está vinculado a la desilusión con el liberalismo, el capitalismo y el marxismo en su capacidad de promover la libertad y la igualdad, así como a la búsqueda de nuevas formas para establecer restricciones legales a los poderes del ejecutivo, para lograr una participación real de la ciudadanía y para promover el bien común, limitando así la posibilidad de los excesos que inspira la búsqueda indiscriminada de la satisfacción individual. De este modo, el republicanismo sería una alternativa no socialista al capitalismo y a la globalización. En palabras de Appleby:

Después de la melodía única del progreso liberal, la rica sinfonía de la ideología, orquestada por las necesidades humanas y armonizada por instituciones sociales, fue música a los oídos de una generación que había descubierto la cultura.

16 Wood, 1969. Baylin, 1967. 
Sin embargo, ella sostiene que la vuelta a los orígenes para modificar la filosofía de la historia construida a partir de la modernidad liberal e intercambiarla por el republicanismo clásico significa dejar sin sustento «el mito de la creación nacional» ${ }^{17}$.

A partir de la discusión anterior, resulta pertinente hacer la siguiente pregunta: ¿Cuál es la trayectoria del republicanismo peruano, tanto en su dimensión conceptual como en su aplicación práctica? ${ }^{18}$. Las primeras reflexiones que surgen en el Perú sobre el concepto de «república» están relacionadas a dos de las acepciones dadas a dicha voz en el Diccionario de la Lengua Castellana de 1737: la de «res pública» o cuerpo político, y la de pueblo o ciudad. Con respecto a la primera, José Ignacio de Lequanda, redactor del Mercurio Peruano (1791-1795), señalaba que la falta de empleo y las pretensiones sociales de las clases menos privilegiadas eran responsables de los daños morales y políticos que sufría el Virreinato del Perú, lo que estaba llevando a «la República a su propia ruina» ${ }^{19}$. El concepto de «república» que manejaron los redactores del Mercurio exhibe un aire de familia con el humanismo cívico de estirpe latina. Para el mismo, el orden, la moral y la virtud eran los fundamentos de toda sociedad civilizada. Este discurso republicano primigenio distó de ser monolítico, y por tal razón, para comprenderlo se debe considerar también su conexión con la tradición hispánica. Esta, al igual que el republicanismo clásico - pero contraponiéndosele por su tendencia de hacer prevalecer, como lo señala Skinner, «la razón de Estado» por sobre todas las demás-, promovió el accionar del «hombre virtuoso, cristiano y de buena opinión» para la búsqueda del «bien común de la República». No ser «un buen republicano», es decir, despreocuparse por la cosa pública, podía acarrear «la confusión de todo el cuerpo social» ${ }^{20}$.

Acerca de la segunda acepción dada en el Diccionario, la de pueblo, ella guarda relación con el sistema político implantado por España en el ámbito local. De acuerdo con la teoría legal hispánica, la Corona dispensaba privilegios y estipulaba obligaciones - obviamente distintos y desigualesa cada república-nación, tanto de indios como de españoles. La legislación se tradujo en las «reducciones» de indios, los que fueron reubicados en "pueblos cristianos», donde al vivir «en república» serían capaces de adquirir las virtudes, la civilidad cristiana y el buen gobierno. La «República o pueblo de Indios» emerge en el Perú, en medio de la crisis del siglo XVII,

17 Appleby, 1992.

18 Para esta discusión, ver McEvoy, 2009: 1345-1357.

19 Mercurio Peruano, 13 de febrero de 1794.

20 Sánchez Concha, 1999: 112-114. 
como el foco de la cultura política, judicial y religiosa de su población indígena ${ }^{21}$.

El concepto de república estuvo asociado, por otro lado, con el saber ilustrado, sus mecanismos de difusión y sus representantes más preclaros. Eusebio de Llano y Zapata opinaba que la biblioteca y los periódicos eran los espacios más favorables para la construcción de una «república de las letras» ${ }^{22}$. De la interesante relación entre la república y el saber ilustrado dio cuenta un redactor del periódico El Peruano, quien en plena primavera liberal recordó que «la ruina de las repúblicas» se debía al «egoísmo fatal» de su sector pensante ${ }^{23}$. Unos años después y con ocasión de su elección como presidente del Congreso, Unanue se dirigió a los «sabios de la universidad de San Marcos» para asegurarles que la «ignominia» contra ellos había cesado y que desde ese momento «la república» reconocería el valor de los hombres formados en «la ciencia y la virtud» ${ }^{24}$.

En la medida que el triunfo patriota redefinió un contexto y sentó una agenda política novedosa, el concepto de república se verá asociado tanto a un gobierno diametralmente opuesto al de la monarquía absoluta como a la nueva sociabilidad practicada por los «hombres de mérito», una categoría que les fue otorgada en exclusividad a los republicanos ${ }^{25}$. El contrapunto con un pasado inmediato al que se considera nefasto se convierte así en un arma retórica para la lucha por la legitimidad simbólica. De acuerdo con Manuel Lorenzo de Vidaurre, la diferencia entre monarquía y república radicaba en el hecho de que en un gobierno republicano «la virtud» era el principio rector, mientras que «el camino de las dignidades» formado «por la infamia y corrupción» era la base del sistema monárquico ${ }^{26}$. En un escenario donde lo que primaba era la propaganda ideológica, los preceptos primordiales de la república se verán relacionados con una serie de condiciones básicas, siendo la principal que todos los hombres nacían libres y con igualdad de derechos. El fin de una asociación política de corte republicano consistía en mantener los derechos naturales imprescriptibles del hombre, es decir, la libertad, la propiedad, la seguridad y la capacidad de resistir la opresión ${ }^{27}$.

A partir de la década de 1820, las ideas liberales estuvieron asociadas a la división de los poderes del Estado, el igualitarismo, la libertad negativa, la pri-

21 Thurner, 1997: 6-7.

22 Tauro del Pino, 1951: IX-XVII.

23 El Peruano, 17 de septiembre de 1811.

24 Unanue, 1974: 839-842.

25 El Tribuno de la República, 15 de diciembre de 1822.

26 Vidaurre, 1971b: 358-359. Para un análisis reciente del discurso y la praxis de Vidaurre, ver Peralta, 2010: 309-337.

27 Vidaurre, 1914b: 373. 
macía de la ley y el predominio del gobierno constitucional. No bastaba conseguir la independencia, era necesario consolidarla, y la única manera de lograrlo era que los peruanos se «constituyesen» y que sus leyes fundamentales fueran revestidas de «decoro y majestad» ${ }^{28}$. La influencia de John Locke se hizo evidente en la discusión propiciada desde las páginas de Los Andes Libres, donde se asoció la ley con la libertad ${ }^{29}$. Locke fue citado por los autores peruanos para validar una serie de conceptos muy cercanos al ideario liberal, como el de la libertad («facultad que tenía un hombre de hacer lo que le pareciere siempre y cuando no dañara a otros hombres»), el de la igualdad («derecho a ser protegido en sus medios y en sus facultades sin diferencia de unos hombres a otros») y el de la propiedad («facultad exclusiva de disponer y gozar a nuestro arbitrio del producto de nuestro trabajo») $)^{30}$. Existía un consenso entre los participantes de aquella intensa discusión pública - a la que Jorge Basadre denominó el primer ciclo doctrinario peruano ${ }^{31}$ - respecto de que la soberanía residía en el pueblo y, por ende, era este el que debía elegir a sus «representantes para pronunciar su voluntad» ${ }^{32}$. En el texto titulado Aptitud civil de la república, que se le atribuye a Sánchez Carrión, «la ley» era presentada como el eje y motor de la sociedad. La tarea de los poderes públicos era servir a esta última con «sabiduría y energía» ${ }^{33}$. Otro elemento fundamental para la buena marcha de un gobierno era la opinión pública. De acuerdo con Sánchez Carrión, el «poder irresistible de los gobiernos liberales», como lo era la opinión pública, jugó un papel fundamental en la independencia peruana ${ }^{34}$. Una educación ilustrada era requisito sine qua non para la concreción de la agenda liberal. Un pueblo ignorante jamás podría disfrutar las ventajas de la libertad. Si el Perú quería ser parte de una «sociedad civilizada», era necesario que sus autoridades promovieran «la adquisición de conocimientos» ${ }^{35}$. Los redactores de La Abeja Republicana eran de la opinión que una vanguardia inte-

28 La Abeja Republicana, 10 y 13 de octubre de 1822.

${ }^{29}$ La frase «donde no hay ley no hay libertad» apareció en Los Andes Libres, 17 de noviembre de 1821.

30 El Diario de Lima, 13 y 16 de noviembre de 1822.

31 Basadre, 2002. La publicación de las Bases de la Constitución de 1822 y la dación de la Constitución de 1823, son dos hitos de una larga polémica que se inició luego de la caída del Protectorado (1821-1822).

32 La Abeja Republicana, 5 de septiembre de 1822; El Brujo, 13 de septiembre de 1822; y El Loro, 30 de septiembre de 1822.

33 El Tribuno de la República, 12 de diciembre de 1822.

34 El Correo Mercantil, Político y Literario, 18 de enero de 1822; y La Abeja Republicana, 14 de noviembre de 1822 .

35 El Brujo, 30 de agosto de 1822. 
lectual responsable debía preparar al pueblo para vivir en libertad. La instrucción era, en consecuencia, la brújula que indicaba la ruta que debía seguir la república ${ }^{36}$.

Para los liberales peruanos, la libertad, la igualdad ante la ley y el cumplimiento cabal de esta última eran «los verdaderos resortes de la felicidad y prosperidad de los estados $»{ }^{37}$. La celebración de la trilogía libertad, igualdad y justicia no logró desterrar, sin embargo, el cúmulo de contradicciones que marcó a una tendencia ideológica que antes de convertirse en opción política exhibió una carga semántica ambigua ${ }^{38}$. Una serie de situaciones específicas, entre ellas la ausencia de un hinterland económico para los mentores del ideario liberal (los que en su mayoría eran clérigos y abogados), la inexperiencia política de sus líderes (en el Perú no se organizaron, como en otros lugares, juntas de gobierno) y el evidente desfase histórico de las fórmulas políticas que se articulan en el ex virreinato (en comparación con los cambios ideológicos que estaban ocurriendo en el escenario internacional), hizo complicada la tarea de los liberales peruanos, quienes no lograron una hegemonía similar a la de sus pares rioplatenses o mexicanos. A las limitaciones anteriores habría que agregar la presencia de la agenda bolivariana, que tuvo como uno de sus objetivos principales el sometimiento de los políticos peruanos. Ello a pesar que en vísperas de su llegada, Simón Bolívar fue definido como «el único modelo cumplido del liberalismo verdadero». El redactor de El Nuevo Día del Perú afirmaba que existían dictaduras déspotas y otras tendientes a la consecución de «la libertad de los pueblos» ${ }^{39}$ — la bolivariana correspondía a esta última categoría - La resignificación del concepto «liberal», producto de una guerra larga y compleja y de la impotencia civil en un escenario cada vez más militarizado, fue preparando el escenario para la hegemonía de los generales peruanos, quienes en su camino a la consecución del poder se valieron, como veremos más adelante, de la prédica republicana, tanto en clave liberal como conservadora. Así, el republicanismo, asociado a la noción de ciudada-

36 La Abeja Republicana, 9 de agosto de 1822.

37 La Abeja Republicana, 1 de febrero de 1822.

38 Samuel Rivera opina que es significativo que ni el concepto «liberalismo» ni sus afines, como «liberal», sirvieran de manera inequívoca para dar etiqueta a grupo alguno hasta mediados del siglo XIX. Esto indica que «liberal»o «liberalismo» como nombres de una unidad programática carecían o bien de la precisión semántica o bien del prestigio valorativo que se requiere para que un sector político pueda identificarse con un rótulo cualquiera. El autor observa incluso que en las décadas posteriores a la independencia existía una percepción dual del liberalismo. En algunos casos, dicha ideología se vio asociada a la anarquía y al desorden. Para esta discusión, ver Rivera, 2009: 808-823.

39 El Nuevo Día del Perú, 25 de septiembre de 1824. 
nía en armas, tuvo muchos seguidores entre los miembros de la corporación militar ${ }^{40}$.

En 1822, nación y república aparecen oficialmente como términos equivalentes. Dentro de una línea de interpretación político-territorial, las Bases de la Constitución de ese año se encargaron de señalar que «todas las provincias reunidas en un solo cuerpo» formaban «la nación Peruana», la que debía denominarse «República Peruana» ${ }^{41}$. Más adelante, en la Constitución de 1828, la «República Peruana» se verá asociada al binomio Estado-nación, en el sentido de que «la nación peruana» será definida como «la asociación política de todos los ciudadanos». La ecuación entre república y gobierno nos habla, por otro lado, de las dimensiones político-administrativas de ese concepto. El «gobierno republicano representativo», que en palabras de uno de los redactores de $L a$ Abeja Republicana era el único capaz de «hacer libre y feliz al Perú» ${ }^{42}$, era concebido como «una gran máquina compuesta de infinitas ruedas», cada cual con su propio destino. Si una de sus partes se alteraba o descomponía, las consecuencias eran sentidas en «el movimiento general» de la nación. Organizar esa inmensa asociación en la que debía conciliarse «la soberanía natural de cada socio» con «los intereses públicos» era, sin lugar a dudas, inmensa, porque el pacto sobre el que se sustentaba la república obligaba a los miembros a ayudarse mutuamente «con sus talentos y sus fuerzas». La mayor falta contra ese «contrato sagrado» era negarse a poner en movimiento las propias «aptitudes» en beneficio del conjunto social ${ }^{43}$.

$\mathrm{La}$ «gobernabilidad republicana» era un aspecto del nuevo orden que preocupaba a Manuel Lorenzo de Vidaurre, porque en las repúblicas «todos» se contemplaban «iguales» y, por ello, todos pretendían, acechaban o envidiaban al gobierno. De esta nefasta actitud se derivaban tres consecuencias: 1) «los continuos partidos y odios insanables» (una obvia referencia a los faccionalismos); 2) «la ninguna fijeza en el modo de gobierno, variando con los dictámenes», y 3) «la desesperación de los ciudadanos postergados», que, por lo general, incurrían «en perfidia y enemistad de su patria» ${ }^{44}$. El acto mismo de «constituir una República», la cual era - para Luna Pizarro - un sistema de gobierno y una comunidad nacional, resultaba «una obra altamente difícil» de lograr. El proceso era arduo debido a que aquella presuponía la impo-

\footnotetext{
40 Esta discusión ha sido desarrollada en McEvoy, 2011a: 207-244.

41 Constituciones politicas, 1922: 27-32.

42 La Abeja Republicana, 1822, Prospecto, s/f.

43 Vidaurre, 1971d: 425 y 437.

44 Vidaurre, 1971: 178.
} 
sición de «principios uniformes» $»^{45}$, los que tenían por finalidad poner «en concierto los elementos heterogéneos» que componían el cuerpo político peruano ${ }^{46}$. La necesidad de «acordar opiniones» que luchaban entre sí; el combate contra intereses indignos de protección, los que osaban presentarse bajo las formas del bien público; y la necesidad de forzar el sacrificio individual «en aras del verdadero bien nacional» eran parte del diagnóstico y de la agenda que Luna Pizarro estableció para los republicanos peruanos ${ }^{47}$. En su artículo «Carácter del verdadero republicano», escrito en 1824, Hipólito Unanue delineó un modo de ser político a tono con la visión de Luna Pizarro. El «verdadero republicano» era, siguiendo sus pautas, «el hombre libre, bajo la égida de la ley» que él mismo había dictado. Este nuevo actor social debía exhibir una serie de virtudes, siendo las más importantes el amor a la patria y el deber para con ella, la franqueza, la imparcialidad, el respeto por el mérito ajeno, la tolerancia y el espíritu público. El comportamiento anterior le permitía desmarcarse de los actores del pasado (los vasallos) y de los del presente inmediato, los «patriotas exaltados», quienes desconocían la moderación y, por ello, conducían a la república a la «fatal anarquía» ${ }^{48}$.

\section{LA PATRIA CIENTÍFICA Y SUS DEFENSORES}

Fundada en 1822, la Sociedad Patriótica de Lima fue un espacio de sociabilidad ilustrada, una esfera en la que se irá definiendo una rama del republicanismo a la cual denominamos la «patria científica». Este concepto está relacionado con la reconstrucción del poder económico, político y cultural del Estado y de sus tradicionales agentes. Estos fueron un grupo de médicos y científicos formados en la facultad de Medicina de San Fernando. Cabe recordar que Hipólito Unanue, vicepresidente de la Sociedad Patriótica, y José Gregorio Paredes, su discípulo más cercano, participaron en el desarrollo de la medicina nativa. Fue por medio de la intensa experiencia de la Sociedad, que apunta al concepto de la república como espacio cultural pero también como instrumento de desarrollo material, que un grupo de médicos peruanos irá modelando un utillaje mental basado en la reflexión y el rigor académico, así como en la aproximación empírica y minuciosa de la fisiología del cuerpo humano. Es importante subrayar que el proyecto de la comunidad científica limeña, que

45 La Cola del Cometa, 29 de marzo de 1827.

46 Luna Pizarro, 1959: 22.

47 Ibidem: 195.

48 Unanue, 1974: 23. 
era su hegemonía cultural, se logró mediante sus vinculaciones con el poder en diferentes etapas: la primera con el virrey Abascal, la segunda con José de San Martín y la última con Simón Bolívar, con cuyo gobierno se forjó una alianza estratégica. Lo anterior tuvo por objeto encauzar las influencias y las relaciones políticas de los fernandinos en provecho de la práctica científica ${ }^{49}$.

Si se analiza el formato de la Sociedad Patriótica de Lima, es posible afirmar que ella formó parte de la tendencia de crear sociedades del conocimiento, que desde mediados del siglo XVIII en adelante surgen en Europa. Los peruanos contaban con una experiencia excepcional: la Sociedad de Amantes del País. Las sociedades del conocimiento decimonónicas, conformadas por «la aristocracia del talento», fueron espacios de sociabilidad urbana en donde la capacidad individual y el estatus fueron relacionados al trabajo intelectual. En la conformación de las sociedades del conocimiento europeas, donde la devoción a la ciencia y no las cuestiones políticas o religiosas constituían el objetivo principal de sus miembros, se nota un «eclecticismo» muy similar al que exhibió la entidad limeña liderada por Monteagudo. Así, bajo el alero de la ciencia, convivieron representantes de la nobleza peruana, de la iglesia, de la universidad e incluso algunos burócratas estatales. Lo que les unía era su apuesta por una sociabilidad masculina en la cual el ingenio y los buenos modales podrían perfeccionarse mediante una crítica hecha con urbanidad.

La emulación a los clásicos fue otro elemento que modeló a la Sociedad Patriótica de Lima. Porque así como «Virgilio imitó a Homero; Horacio a Píndaro; Cicerón a Demóstenes y los Padres del gusto latino» sirvieron de modelo «a los sabios que les siguieron», los ilustrados peruanos se plantearon como meta «enriquecer el nativo lenguaje con los despojos de los extranjeros y peregrinos ${ }^{50}$. La referencia al paradigma republicano del «magistrado mudo e incorruptible», ante el cual, «en obsequio del bien general», todo se avasallaba, muestra la lectura acuciosa que se hizo de la historia clásica y, además, la importancia que se le dio al concepto de república como gobierno ${ }^{51}$. Dentro de ese contexto, un modelo político a contemplar era el del padre de la república romana, Cicerón, para quien el mejor gobierno sería aquel compuesto del «monárquico, aristocrático y democrático», moderadamente atemperado. Citando a Platón, José Gregorio Paredes recordó que el «primer cuidado de los pueblos» debía ser que mandase la ley y «fuese obedecida desde el primero hasta el último de la sociedad» $»^{52}$.

49 McEvoy, 2011c.

50 El Sol del Perú, 12 de abril de 1822.

51 Ibidem, 13 de junio de 1822.

52 Ibidem, 12 de abril de 1822. 
Dentro de una lógica en la cual se privilegió la excelencia intelectual, la membresía en la Sociedad Patriótica de Lima no se obtuvo con dinero o con un título de nobleza, sino por medio de aquel requisito que el decreto protectoral denominó como «los talentos» o «la profesión de algún arte o ciencia» ${ }^{53}$. La celebración de la inteligencia nativa no fue una idea ajena a los peruanos que participaron de la experiencia de la Sociedad Patriótica de Lima. Ya desde los años de la Sociedad Amantes del País y del Mercurio Peruano, sus redactores, entre los que destacaba Unanue, habían aludido al importante papel que debían cumplir los hombres de letras en la forja de una sociabilidad culta y civilizada $^{54}$. Fue a dicha vanguardia ilustrada, conformada por hombres de «clase media», a la que se refirió Unanue en el discurso que pronunció el 20 de diciembre de 1822 al ser elegido presidente del Congreso. Ahí subrayó la existencia en el Perú de «talentos extraordinarios», con una «constante aplicación» y una «sabiduría adquirida», lo que nunca tuvo más premio que «una dependencia inmediata de europeos orgullosos e ignorantes», porque en el Virreinato del Perú no era «la ciencia» la que ocupaba el «solio de la magistratura», sino más bien la ignorancia y el favor ${ }^{55}$.

Mediante el análisis de las memorias presentadas cada martes y jueves en la Universidad de San Marcos, un lugar que Unanue definió como el rincón de los sabios, es posible acercarse al tipo de discusiones que la Sociedad Patriótica junto con su periódico, El Sol del Perú, propiciaron en el escenario de la Lima post-independencia. No está de más recordar que a pesar de la larga y penosa guerra revolucionaria, descrita de manera magistral por Timothy Anna $^{56}$, la ex capital virreinal no perdió la preeminencia cultural que exhibió durante la colonia. Ello permite entender mejor ese aire de familia entre la Sociedad Patriótica y la Sociedad Amantes del País, fundada por Unanue. Además de defender con tenacidad el americanismo del que estaban imbuidos muchos de sus asociados ${ }^{57}$, la Sociedad Patriótica de Lima y su periódico oficial tuvieron como propósito convertirse en centros de difusión de valores republicanos, aunque, como veremos más adelante, con claras reminiscencias «neoborbónicas».

53 El Sol del Perú, 25 de abril de 1822.

54 McEvoy, 2002: 34-63.

55 Para esta discusión, ver Rama, 1984. Un debate sobre el paradigma impuesto por Rama y su relevancia para los estudios latinoamericanos en Aguirre y McEvoy, 2008: 13-43.

56 Anna, 2003.

57 «Los diversos fragmentos de la monarquía española en América componemos una sola familia unida, a más de los vínculos de sangre, por los de conformidad de carácter e identidad de causa, gratitud de los servicios recíprocos que nos hemos prestado, e interés común contra las acechanzas extrañas», El Sol del Perú, 9 de marzo de 1822. 
En una línea de argumentación que defendió el establecimiento de una cultura más racional y austera, y, por lo mismo, diametralmente opuesta a la de la etapa virreinal, José Gregorio Paredes atacó a «la barbarie» de las «jugadas de toros», argumentando que eran una «insensatez» que ponía en riesgo la vida humana. En el Perú, recordaba el discípulo de Unanue, «toda fiesta, toda función» se solemnizaba con una corrida de toros. Ahí «la deidad idolatrada» demandaba la «oblación» de sangre humana. El espectáculo de los toros era dañino por el enorme perjuicio que causaba a la razón de los espectadores. Mediante una descripción que muy bien pudo ser utilizada para caracterizar una enfermedad mental, Paredes reflexionó sobre el «furor insano» que se apoderaba de los aficionados a los toros, los que se retiraban a sus casas con «un caudal de voluptuosidad y desorden» mental muy superior al que habían depositado «en el fondo común» del «frenesí tauromaníaco». Las «jugadas de toros» tenían efectos concretos no solo en la vida mental, sino también en la subsistencia de los sectores populares. Así, un día de toros era una jornada perdida para el trabajo y los negocios. Paredes celebró, en consecuencia, el decreto protectoral que dictaminó la abolición de una costumbre contraria a la humanidad, porque destruía la moral, la economía y el orden.

Los trabajos que Paredes presentó a la Sociedad Patriótica de Lima fueron más allá de la crítica contra una cultura que la mayoría de los discípulos de Unanue consideraba teñida de tendencias «bárbaras». En una de las memorias presentadas en el claustro sanmarquino, el destacado matemático se propuso analizar las bases económicas de la joven nación peruana. Dentro de ese contexto, Paredes, al igual que lo hizo Vidaurre en su momento, opinaba que el Perú vivía adormecido con «el pronto aunque falaz recurso de las minas» ${ }^{58}$. Esa bonanza, hasta cierto punto dañina, fomentó la costumbre de adquirir las «telas, muebles y utensilios» con que «la astucia europea» seducía a quienes, como los peruanos, eran «ciegos imitadores de sus modas y extravagancias». La minería era negativa como única fuente de riqueza nacional, no solo porque creaba el espejismo del «lujo y el esplendor», sino porque introducía «la desigualdad de las fortunas, una de las mayores plagas del Estado y con ello la elevación y opulencia de unos pocos y la abyección y servidumbre de los demás». Paredes, quien subrayó que una independencia política sin su correlato económico era «ilusoria», abogó por el restablecimiento de fábricas a lo largo del país y por la dación de decretos para atraer hombres industriosos capaces de generar trabajo productivo ${ }^{59}$. Aparte de su cerrada defensa de la autosufi-

58 La memoria titulada «Industria» apareció en El Sol del Perú, el 2 y el 9 de mayo de 1822. Para una discusión muy similar a la de Paredes por parte de Vidaurre, ver 1971f: 413.

59 «Tratemos de restablecer las fábricas que estuvieron algún tiempo en uso y dar más ex- 
ciencia económica del Perú, Paredes previno a los miembros de la Sociedad Patriótica de Lima y a los lectores de El Sol del Perú sobre la «coalición mercantil» de las naciones europeas, que no tardarían en unirse contra América mientras esta no se volviera más austera, variando su «régimen económico». En sus palabras, «no era independiente quien no sabía vestirse ni calzarse».

Cabe recordar que José Gregorio Paredes fue un producto de la Universidad de San Marcos y de aquellos Colegios Mayores que produjeron una pléyade de humanistas de la categoría de Pablo de Olavide y Manuel Baquíjano y Carrillo. Entre las décadas de 1780 y 1810, Lima no recibió el influjo de otras regiones hispanoamericanas, sino que más bien las difundió6 ${ }^{60}$. Un ejemplo de esta proyección en el ámbito regional es la participación de Paredes en la creación de un anfiteatro anatómico en Santiago de Chile ${ }^{61}$. En el contexto nacional, el discípulo de Unanue colaboró en el estudio de las ciencias exactas. En la introducción a las Lecciones de Matemáticas, un libro que con el apoyo de la Sociedad Patriótica de Lima fue publicado por la Imprenta del Estado, Paredes rindió tributo a su maestro Unanue. Fundador de la Orden del Sol, consejero de Estado, ministro de Hacienda, vicepresidente de la Sociedad Patriótica de Lima, miembro de las sociedades de ciencias de Baviera, Filadelfia y Nueva York, el ministro de San Martín y después de Bolívar fue quien introdujo el estudio de las matemáticas en el Perú. En efecto, fueron los discursos académicos y privados y las producciones impresas del sabio peruano los que colaboraron en difundir una disciplina reconocida solo por unos «pocos inteligentes». Paredes no olvidaba que su afición a las matemáticas fue lo que cimentó su relación con Unanue, y así lo hizo saber en la dedicatoria de sus Lecciones. Ahí resaltó la deuda intelectual con su maestro, quien mediante su pensamiento científico estaba colaborando en promover la felicidad del Perú ${ }^{62}$.

A partir de la lectura de las memorias escritas por los fernandinos (vinculados al colegio de Médicos de San Fernando) y por las de otros miembros de la

tensión a las existentes, a unas y otras pertenecen: la de paños en Quito, Chillán y Lima; las de brin y otros tejidos de cáñamo en Santiago de Chile; las de algodón para mantelería y otros usos en Eten, Huamanga y Lima; la de vidrios en Cochabamba e Ica», El Sol del Perú, 9 de mayo de 1822.

60 Pacheco Vélez, s.f., refuerza esta afirmación recordando la irradiación regional que tuvo el primer Mercurio Peruano, que sorprendió gratamente a Humboldt; la renovación pedagógica que presidió Toribio Rodríguez de Mendoza en San Carlos; la obra científica de sabios como Cosme Bueno, Gabriel Moreno y, sobre todo, el trabajo extraordinario de Hipólito Unanue.

61 Nota en contestación a un encargo de la Junta de Educación de Santiago de Chile sobre el arreglo de un teatro anatómico, julio de 1813, Archivo José Gregorio Paredes.

62 Paredes, 1822. 
Sociedad Patriótica de Lima es posible evidenciar la relación entre el proyecto cultural y el económico de una intelligentzia que, como la peruana, apostó por esa suerte de dictadura militar de corte ilustrado que fue el Protectorado ${ }^{63}$. La república en su versión conservadora, además de ser una forma de gobierno con autonomía económica, era también percibida como un instrumento de moralidad. La república era el mecanismo para resolver el grave problema de la ausencia de virtud, un hecho que estaba relacionado con el lujo de las clases propietarias o con la irracionalidad popular que se manifestaba en las «jugadas de toros». Los excluidos de esta suerte de «pacto moral» planteado por los fernandinos eran «el perezoso y el indolente», el «solicitante inoportuno de honores» y el «negociador de privilegios» ${ }^{64}$. De esa manera, trabajo y virtud se convirtieron en las dos caras de una misma moneda, y era la competencia de un gobierno asistido por las «luces» el llevar adelante un proyecto económico y a la vez moral. Para Unanue, el «alma de una nación» era «el gobierno»; aquella era grande y gloriosa si este era «ilustrado, justo y activo»; y, por el contrario, era «infeliz, holgazán y perezoso» si este carecía «de luces, equidad y energía» ${ }^{65}$.

Debido a que los medios que utilizaron los fernandinos para trasmitir sus propuestas fueron memorias de varias páginas o conjuntos de lecciones como las señaladas anteriormente, resulta obvia la ausencia de un interés similar al de los redactores de La Abeja Republicana por llegar a un público masivo y popular. Eso lo tenía muy claro el mismo Paredes cuando advirtió que escribir en «estilo bajo y humilde» no era algo que se le ocurriría a «un hombre de buen sentido, ni en los tiempos antiguos ni en los modernos ${ }^{66}$. Para entender esta vertiente republicana que pensaba que la construcción de un proyecto político no podía ser «producto de las circunstancias efímeras o raptos apasionados», sino de las «contemplaciones de ciertos hombres extraordinarios», quienes en la «tranquilidad» de sus gabinetes concebirían una serie de «conceptos» capaces de transformar la «faz del orbe», es importante recordar la vida y obra de un grupo de médicos peruanos y el papel que algunos de estos personajes cumplieron en la fundación del Anfiteatro Anatómico, en la creación de la Escuela de Medicina de San Fernando, en la Sociedad Patriótica de Lima y, posteriormente, en el gobierno del país. Aquí me estoy refiriendo a la partici-

63 Se denomina Protectorado al gobierno que sucedió a la independencia y que, entre 1821 y 1822, encumbró al general José de San Martín como protector del Perú. Para un análisis de la estructura política que sostuvo al protectorado, ver McEvoy, 1999: 1-60.

64 El Sol del Perú, 27 de junio de 1822.

65 El Verdadero Peruano, 1 de octubre de 1812.

66 El Sol del Perú, 12 de abril de 1822. 
pación de los fernandinos en los ministerios y en el Congreso. Esto último incluye el ejercicio de su presidencia y vicepresidencia, pero además su labor simbólica en el diseño del escudo del Perú ${ }^{67}$.

\section{LA DIMENSIÓN LIBERTARIA DE LA REPÚBLICA}

El discurso pronunciado por José Ignacio Moreno en el seno de la Sociedad Patriótica de Lima, en marzo de 1822, definió los términos de la discusión respecto del tipo de gobierno que el general José de San Martín, su ministro Bernardo Monteagudo y sus seguidores en el Perú creyeron más conveniente para el ex virreinato. La nación peruana acababa de salir del «oscuro caos» al que lo había sometido la dominación española, y por tal razón se hallaba en «la infancia de su ser político». Compuesta por un pequeño número de hombres ilustrados y rodeada por una gran masa heterogénea que aún yacía en las «tinieblas de la ignorancia», el peligro más acuciante era la «discordia» entre las diversas castas que constituían su población. La «habituación» a la obediencia de los reyes hacía imposible la instauración en el Perú de «la rigorosa democracia». Así, la única solución política era una monarquía constitucional, porque el mayor peligro de la alternativa republicana era que una democracia equivocada derivara en «oclocracia» y luego en una anarquía que todo lo devorara $^{68}$. En un escenario en el que la apuesta fue por una monarquía constitucional, el concepto de república se vio asociado con el de «una democracia equivocada», la que fue vista como fuente de inestabilidad y de desorden social. Cabe recordar que unos meses antes de la discusión en la Sociedad Patriótica de Lima, uno de los editoriales de Los Andes Libres alertaba a los peruanos sobre el riesgo de caer presa de los «los delirios de la utopía» si es que copiaban ensayos políticos tan peligrosos como «la exaltación republicana de Carnot» ${ }^{69}$.

La discusión entre monárquicos y republicanos permite revelar la incompatibilidad, percibida por los primeros, entre la república soñada y la heterogeneidad social y cultural propia del Perú. La defensa del orden republicano, «el más digno e ilustre» que podía darse a «la raza humana», da cuenta, por otro lado, de la intencionalidad pedagógica que asume el republicanismo peruano y de su estrecha asociación con al menos tres conceptos: la libertad, la opinión

67 Sobre el proceso de elaboración del escudo nacional y el papel que le correspondió a José Gregorio Paredes, consultar Majluf, 2006: 203-241.

68 El Sol del Perú, 28 de marzo de 1822.

69 Los Andes Libres, 7 de agosto de 1821. 
pública y la ciudadanía. De acuerdo con Sánchez Carrión, el objetivo de la independencia fue «la libertad», sin la cual «los pueblos eran rebaños y toda institución inútil». Dentro de esa lógica, la monarquía era «una herejía política» para un «estado verdaderamente libre» como el peruano ${ }^{70}$. El arraigo en el Perú de una cultura cortesana abonaba el argumento a favor de un gobierno republicano capaz de «frustrar los ardides del despotismo» y «los siniestros principios de una política rastrera ${ }^{71}$. El régimen monárquico, en donde lo que primaba era el «arte de pretender» y la indolencia frente a la verdad y «la salud de la comunidad», era una amenaza constante contra «las virtudes cívicas» sobre las que debía asentarse la república, porque «debilitada» su fuerza y «avezados al sistema colonial», los peruanos serían, bajo una monarquía, «excelentes vasallos y nunca ciudadanos» ${ }^{72}$. El argumento esgrimido por Sánchez Carrión de que la discusión propiciada por el Protectorado no era «una negociación de gentes privadas», unido al ataque contra la «política clandestina» del régimen por parte de los redactores de La Abeja Republicana, muestran que la batalla decisiva por la causa de la república ocurrió en la esfera de la opinión pública ${ }^{73}$. En su Prospecto, ese periódico recordaba que «la imprenta» era el único medio de «contener a los déspotas» y de «dirigir la opinión de los ciudadanos».

La solución del dilema republicano debía darse en un contexto histórico y sustentarse en la experiencia. Dentro de ese contexto, el mayor desafío era crear «un gobierno central, sostenido por la concurrencia de gobiernos locales». Sánchez Carrión evidenció su pragmatismo cuando señaló que el uso de «puras teorías» para repeler un ensayo político no exento de complicaciones era un «verdadero crimen» ${ }^{74}$. Asumir, como lo hizo la primera generación de republicanos peruanos, la tarea de construir una república en el territorio de la contingencia nos permite comprender la naturaleza constructivista del proyecto republicano que se ensaya en el Perú. Expuestos a los vaivenes de un accionar pragmático e intencional, los republicanos debían acercarse a la historia para aprender las valiosas lecciones del pasado. En efecto, la experiencia, «consignada en los anales de todos los siglos», daba cuenta de los peligros que acechaban a una «república mal constituida», porque «nunca fue más tiranizada la república romana que cuando la rigieron los decenviros» o cuando «Marat y Robespierre, humanados tigres, casi dejaron yerma la Francia». La Cons-

\footnotetext{
70 Sánchez Carrión, 1974a: 349-359.

71 El Tribuno de la República, 5 de diciembre de 1822.

72 Sánchez Carrión, 1974a: 349-359.

73 La Abeja Republicana, 22 de agosto de 1822. Martínez Riaza, 1985.

74 Sánchez Carrión, 1974a: 349-359.
} 
titución era otro de los resguardos que la república tenía contra «la liberticida ambición» de sus «pretendidos legisladores». Preservar a la república de su peor enemigo, la anarquía provocada por las facciones, requería de la división de poderes, del ejercicio permanente de la ciudadanía y de la unión estrecha entre los partícipes del pacto republicano. La construcción de una república en un «vasto Estado» como el peruano, lo que fue visto por los monárquicos como un problema insalvable, dependía de la buena marcha de «la administración municipal», la que fue considerada desde sus inicios como la piedra angular del sistema republicano ${ }^{75}$.

La Municipalidad de Lima desempeñó un rol estelar en la caída del régimen protectoral. Así, la misma comunidad de la capital — utilizando una forma de representación colonial como el cabildo abierto - terminó erigiéndose en representante de una nación amenazada por las políticas protectorales. $\mathrm{La}$ alianza de los núcleos sobrevivientes de la aristocracia colonial con «los hombres de bien» y los sectores populares brinda interesantes pistas para entender los pilares de la cultura política limeña y la ideología montada en la travesía desde el orden colonial al republicano. El «compacto social» que derrocó a Monteagudo habla sin duda de la relación simbiótica entre la sociedad plebeya y la patricia durante el periodo colonial. Por lo anterior, no resulta casual ver a los sectores populares limeños demandando la intercesión de la municipalidad para dar trámite legal a su pedido $\mathrm{y}$, una vez conseguido, presionar por un juicio de residencia contra Monteagudo. En cierta manera, se pretendía proceder con el ministro de Estado del régimen protectoral tal como se habría hecho anteriormente con cualquier otro funcionario colonial inepto ${ }^{76}$.

Los miembros del primer Congreso Constituyente, que se inauguró en 1822, luego de la caída del Protectorado, llevaron a cabo la tarea de desconcentrar el poder que Monteagudo intentó sin éxito centralizar. En efecto, en el desarrollo de sus actividades el Congreso Constituyente exhibió dos propuestas que reflejaron las tendencias más radicales del republicanismo en clave liberal, a la vez que expresaron su resistencia frente a cualquier poder ajeno al del Parlamento. La decisión de elegir una Junta Gubernativa, en medio de la guerra, con miembros de su seno, y la elaboración de una Constitución marcadamente asambleísta, la que restringía las facultades del ejecutivo, dejaron de lado la posibilidad de aquello que Benjamín Constant definiera como un poder moderador. En las tres proposiciones hechas por el liberal arequipeño Mariano Arce, este observó que el Congreso debía retener «cuanta autoridad» le fuera posible para así evitar la

75 Sánchez Carrión, 1974b: 366-378.

76 McEvoy, 1999. 
hegemonía del ejecutivo. Por tal razón, este adoptó la forma de un triunvirato, que estaba conformado por miembros de la Cámara de representantes. Arce imaginó, así, un legislativo todopoderoso cuya finalidad era resguardar «la libertad y seguridad del cuerpo Soberano», que en todo momento debía gozar de una «total independencia constitutiva». A raíz de que los miembros del Congreso se sintieron obligados a cumplir funciones regeneradoras, dicha institución se eximió de «las reglas ordinarias propias de una mera legislatura». Cabe recordar que debido a la tarea que se le había encomendado (la de definir el gobierno y redactar la primera Constitución de la flamante República), la situación del Congreso Constituyente fue en verdad extraordinaria.

Un sector moderado de los liberales, para el cual la división de poderes era la única manera de conseguir una libertad efectiva y duradera, criticó la fórmula de Arce argumentando que mantener un poder que correspondía al ejecutivo podía terminar en el despotismo, al ver «reunidas en una misma persona la facultad de dictar leyes, y la de ejecutarlas». Sánchez Carrión, uno de los críticos del modelo de inocultable estirpe jacobina, recordó incluso los sucesos que dieron origen y luego liquidaron al régimen instaurado por Robespierre. Estos males, creía, provenían de la retención por parte de la Asamblea de Francia de las facultades de hacer y, al mismo tiempo, ejecutar las leyes. La respuesta de Arce fue clara y contundente. Su opinión era que si se tomaba en cuenta el pasado histórico, todas las asambleas constituyentes habían sucumbido luego de que el poder ejecutivo fue colocado en manos extrañas ${ }^{77}$. Por lo anterior, Marco Jamanca afirma que el régimen político inaugurado por los republicanos-liberales en la Carta de 1823, quienes por mayoría decidieron preservar el poder del ejecutivo, no puede ser definido ni como parlamentario ni como presidencial. El asambleísmo ${ }^{78}$, que es la fórmula política que los liberales radicales le impusieron a la primera república peruana, muestra cuán alejados estaban sus voceros de los modelos constitucionales en boga, más aún cuando el experimento que se intentó implementar en el último bastión colonial había fracasado en todos los lugares donde fue aplicado ${ }^{79}$.

77 Para esta discusión fundamental, ver Jamanca Vega, 2007.

78 «En el gobierno de asambleas, la asamblea legislativa que es elegida por el pueblo está dotada del dominio absoluto sobre los otros órganos estatales, y solo será responsable ante el electorado soberano encargado de renovarla con intervalos regulares de tiempo. En oposición a la estructura dualista del gobierno parlamentario - que en teoría supone la existencia de dos detentadores del poder independientes, la asamblea y el gobierno-- en el régimen de asamblea el ejecutivo está sometido a la asamblea siendo tan solo su servidor. La delegación de la asamblea exhibe un carácter técnico y no le provee al ejecutivo con ningún derecho, salvo el otorgado por la mima asamblea» (Jamanca Vega, 2007).

79 Luego de la caída de Napoleón Bonaparte, el liberalismo francés decidió desembarazar- 
La circular a los prefectos escrita en 1826 por José María de Pando, ideólogo del partido republicano-conservador, puede brindar ciertas luces sobre las consecuencias políticas del liberalismo radical que se instauró en el Perú luego de la caída del protectorado. Pando opinaba que los poderes «mal equilibrados» en el Congreso «entraron en una lucha funesta». Los «resabios de la servidumbre en pugna con los sueños de una libertad desordenada, produjeron choques insensatos, aspiraciones ambiciosas, criminales defecciones». Dentro de ese contexto, las clases que se creyeron maltratadas por la nueva Constitución, marcadamente radical, opusieron la inercia o bien maquinaciones encubiertas a la marcha del régimen liberal. Por otro lado, las violencias de autoridades subalternas no reprimidas por un «poder central y vigoroso» disgustaron a los pueblos, que no se curaban de «vanas teorías, sino de buenos efectos prácticos de las leyes». Fue así que el desorden, la desobediencia y la dilapidación se introdujeron en todos los ramos de la administración de la joven república peruana, y cuando ello ocurrió, llegaron «la sedición y la alevosía». En ese complejo escenario, el mismo Congreso, ya desbordado por las facciones en pugna, se vio forzado a destruir su propia obra y crear el «tremendo poder de la Dictadura», ante el cual «las cosas y las personas» finalmente «enmudecieron» ${ }^{80}$.

\section{LA REPÚBLICA MILITARIZADA}

Una república que no recurría a un dictador, señalaba Manuel Lorenzo de Vidaurre, gran admirador de Maquiavelo ${ }^{81}$, estaba condenada a perecer en medio de los «terribles terremotos políticos» originados en el proceso de su misma creación. Dentro de esta línea argumentativa, el dictador era «un ciudadano» a quien se le habilitaba para que procediera «sin fórmulas, dilaciones y aparatos» a conseguir el bien público. Cuando un país, como fue el caso del Perú en vísperas de la llegada de Bolívar, se encontraba reducido «al miserable

se del pesado equipaje de máximas abstractas y apotegmas revolucionarios. Así, a partir de 1814 se desencadenó, en Francia y en el resto de Europa, un verdadero furor contra todo lo que en materia de reflexión política y constitucional guardara relación con el iusnaturalismo dieciochesco y con la «abominable metafísica» de los principios salidos de ese modelo. Para una reflexión sobre este punto, ver Varela Suanzes, 1992: 29-43.

${ }^{80} \mathrm{La}$ circular a los prefectos se encuentra en El Peruano, 8 de julio de 1826 . El decreto del Congreso del 7 de agosto de 1823 señalaba lo siguiente: «que se autorice ampliamente un poder militar con las facultades necesarias a efecto de que haga cuanto convenga para salvar la República», CDIP, XV, Primer Congreso Constituyente, 3, 1971: 175.

81 Sobre la admiración que Vidaurre sentía por Maquiavelo, ver Vidaurre, 1973. 
estado de un gran cuerpo» que se precipitaba en actitud suicida «desde lo alto de una montaña», era imprescindible contar «con un genio activo, veloz y vigilante» capaz de imponer el orden ${ }^{82}$. La dictadura, una suerte de medicina transitoria para una república que, como la peruana, era incapaz de cuidarse por sí sola y menos construir su representación política, fue sancionada mediante el decreto del 10 de septiembre de 1823, el que estableció que «solo un poder extraordinario en su actividad y facultades» era capaz de «poner término a la presente guerra y salvar a la República» de los graves males en que se hallaba envuelta. Ello determinó que, luego del motín de Balconcillo y la disolución del Congreso por parte de José de la Riva-Agüero, el poder de «la suprema autoridad militar en todo el territorio de la República con las facultades ordinarias y extraordinarias» se depositara en manos de Bolívar ${ }^{83}$.

La legitimación ideológica de la dictadura militar no concluyó con la breve etapa bolivariana. El complejo sistema que pusieron en marcha los militares, en complicidad con los civiles - y que fue descrito por Francisco de Paula González Vigil como una «tiranía» que, bajo el pretexto de velar por «la salud del pueblo», empeoraba la «suerte de la patria disipando su hacienda y poniéndola al borde del sepulcro» ${ }^{84}$ - , fue defendido con elaborados argumentos por los teóricos del autoritarismo peruano, entre ellos José María de Pando, quien durante los años de la república temprana aseguró que «nadie en la infancia» de las instituciones republicanas «podía ceñirse rigurosamente al texto de la ley». Pando fue un activo defensor del poder - casi absoluto - del ejecutivo e incluso abogó por la puesta en marcha de un proceso mediante el cual el gobierno debía generar su propia hegemonía. De lo que se trataba en realidad era de proveer de un blindaje ideológico a ese Estado frágil que, de acuerdo con Felipe Pardo y Aliaga, navegaba a duras penas en medio de una infinidad de tormentas políticas. Si bien es cierto que el manto de legitimidad provisto por el ala conservadora del republicanismo fue de enorme utilidad para la validación de los militares, estos cumplieron también una serie de funciones políticas muy importantes. Los generales, coroneles y capitanes que pelearon en Junín y Ayacucho construyeron, en medio de la inestabilidad civil que sucedió a la independencia, sus redes de poder. Ellos también ensayaron prácticas políticas novedosas e incluso persiguieron objetivos republicanos de largo plazo, como la consolidación del Estado y la promoción de «la reconciliación nacional».

82 Vidaurre, 1971a: 366.

83 Para una interesante discusión en torno a los «poderes de emergencia», que, a diferencia del modelo peruano, son vistos como de término limitado, ver Aguilar Rivera, 2000: 58; y el comentario sobre dicha obra de Gargarella, 2002: 462.

84 González Vigil, III/1 (Lima, 1951-1955): 437. 
La lectura de la Memoria escrita por el general Domingo Nieto, publicada en Lima en $1839^{85}$, permite observar cómo el vocabulario republicano-liberal logró infiltrar a los militares. A pesar de la evidente filiación castrense que provino de su participación en la guerra de independencia, Nieto defendió su posición frente al «partido de la fuerza», representado por su camarada de armas, el general Agustín Gamarra. A diferencia del hombre que pasó a ser su enemigo jurado, Nieto enarboló valores de inocultable estirpe liberal. La «justicia a favor de los derechos comunes», la «libertad de los pueblos», la soberanía de la nación peruana, el voto popular, la importancia de la ciudadanía, el gobierno de la ley y el respeto por la opinión pública se convirtieron en los principales pilares de la república peruana imaginada por los militares. Describiéndose como «siempre franco y siempre republicano», el general Nieto subrayó en su Memoria opiniones, sentimientos y principios políticos tendientes a obtener la regeneración del Perú por medio de la eliminación de los faccionalismos. Dentro de un corpus conceptual que lograba combinar sin mayores problemas ideas liberales y deseos unanimistas, es posible identificar una de las mayores obsesiones de Nieto y de la corporación militar de la cual fue vocero. Para el «soldado de la república», las disensiones intestinas eran causa exclusiva de «todos los infortunios» del Perú ${ }^{86}$.

El levantamiento de Arequipa contra el continuismo que intentó imponer el general Gamarra puede brindar luces sobre la república militarizada y el ciudadano en armas que le sirvió de sustento. Dentro de este contexto, 1834 es un año decisivo para la organización política e ideológica del Perú post-independencia, y por tal razón, en esta última sección analizaré la génesis de un movimiento armado que estableció el derrotero del proyecto republicano en clave militar. La revolución de Arequipa contra Gamarra y sus allegados servirá de modelo para otras asonadas que se suceden a lo largo del tempestuoso siglo XIX. En una carta que le escribió Nieto al presidente Orbegoso desde Arequipa, sale a la luz la motivación ideológica de los defensores de la causa constitucional. El amor por la ley, el odio a la tiranía militar que amenazaba a la patria agonizante y el juramento que obligaba a oficiales y soldados a resguardar a la república contra sus enemigos son las razones esgrimidas por los líderes de una lucha armada, cuyo mayor objetivo fue asumir el liderazgo regional. «Están acuartelados en esta ciudad más de seiscientos cívicos armados y valientes». Los constitucionalistas cuentan además - le escribe Nieto a Orbegoso - con un «sinnúmero de voluntarios» no solo en Arequipa, sino en

85 Nieto, 1839.

86 Ibidem: 39. 
las provincias aledañas. De esa manera, jóvenes aguerridos y veteranos de la guerra de la independencia se aunaban para llevar a cabo la guerra cívica, liderada por el flamante jefe político militar de los departamentos del sur, quien mediante oficios enviados a los prefectos del Cuzco y Puno buscaba expandirla a toda la región.

La guerra cívica modeló los usos y las costumbres políticas de la república temprana. La alianza caudillo-pueblo, de la que ha dado cuenta el excelente trabajo de Gabriella Chiaramonti y de la cual Arequipa es un ejemplo temprano, planteó una disyuntiva difícilmente superable entre la representación liberal de la sociedad y su contraparte corporativa ${ }^{87}$. En la larga duración, la alianza entre el militar de turno y las corporaciones que lo apoyaban en su lucha contra el despotismo dificultó la creación de una soberanía moderna, unitaria, absoluta y homogénea. Sin embargo, en el corto plazo la alianza caudillo-pueblo permitió la puesta en marcha del proyecto republicano, en el cual se privilegia ese último concepto. Clement Thibaud observa que la solución provisional al problema de la ciudadanía fue su asociación con la milicia ${ }^{88}$. El «pueblo virtuoso», que en teoría conformaba los ejércitos guerrilleros, actuaba de puente entre el imaginario republicano clásico y el moderno. Así, el momento irregular de la guerra tuvo un mérito incomparable: el de encontrar un pueblo para la naciente república. Esta mediación no solo fue funcional para la relación entre el Estado y el individuo, sino que permitió que ese pueblo huidizo de las constituciones liberales finalmente se corporizara. Refiriéndose a los poderes creadores de la guerra, Thibaud opina que la guerrilla constituyó un crisol de hombres de todos los orígenes y posiciones, unidos en la voluntad de servir a la república. En el caso de la revolución de Arequipa, que es el que estamos analizando, Nieto señaló en una de sus cartas que el comportamiento de los arequipeños era comparable al de los ciudadanos de «las celebradas repúblicas de Grecia y Roma». El general se refería al valor y a la organización de las milicias arequipeñas. El batallón de los Inmortales, por ejemplo, estaba conformado por los jóvenes más atrevidos y robustos de la localidad. Otra de las compañías, denominada de los Tribunos, exhibía a todos los abogados jóvenes, prácticos de derecho y medicina, y otras personas ilustradas de la provincia. El batallón de los Convencionales contenía a los miembros de las primeras familias, mientras que en otra columna de voluntarios destacaban maestros artesanos y comerciantes comprometidos, todos ellos, con la causa de la libertad.

87 Chiaramonti, 2005.

88 Thibaud, 2003. 
En 1834, Arequipa intentó ganarse el apoyo de la opinión pública presentándose ante la nación como el «único lugar donde se podía fundar la esperanza de una resistencia probable a la opresión» del general Gamarra. La libertad o la esclavitud del Perú, señalaba una de las proclamas redactadas en el departamento del sur, dependía de «la ilustración» de los arequipeños. Dentro de ese contexto, el pueblo de Arequipa estaba autorizado a obrar por una «ley suprema de las naciones», que era «la salud de la comunidad». El surgimiento de nuevos liderazgos regionales, como fue el caso de Arequipa, así como el agravio infringido a la Convención Nacional por miembros de la facción asociada al bloque conformado por el Cuzco, Puno y Ayacucho, precipitaron una guerra civil cuyas consecuencias nadie pudo predecir. A partir de 1834, el éxito de un nuevo liderazgo militar radicó en su capacidad de reformular el discurso republicano, cimentando, al mismo tiempo, alianzas en el ámbito nacional. Por tal razón, Nieto firmó docenas de cartas dirigidas a los gobernadores de los pueblos, a quienes les solicitó apoyo material para su guerra revolucionaria contra «los enemigos de la ley». Al igual que los gobernadores, a quienes el general rebelde pidió caballos, bestias de carga, arrieros y gente dispuesta a encajonar los cartuchos necesarios para dar inicio al combate, los subprefectos fueron piezas claves en la puesta en marcha de la guerra revolucionaria que llevó el discurso de la república armada a cada rincón del Perú.

En el esquema de la guerra revolucionaria, cada facción debía exhibir públicamente su poderío, el cual dependía del número de provincias que lograba recabar para su causa. «Contamos con Arequipa, Lima, La Libertad, Junín y Amazonas; y los Gamarras, Bermúdez, Eléspurus y Frías tendrán poder para hacer la guerra a La Libertad y en los tres departamentos restantes», le escribe Orbegoso a Nieto en plena guerra civil de 1834. Lo que queda claro es que solo después de que los agentes de los respectivos grupos en disputa se infiltraban en cada villa, pueblo y provincia para sembrar la semilla de la guerra, era posible dar inicio al torneo militar entre las facciones. ¿Cómo entender la búsqueda de la unidad republicana en este esquema de guerra total entre maquinarias alimentadas con la sangre y el sudor de centenares de pueblos peruanos? El trabajo de Jeremy Adelman sobre «la era de las revoluciones imperiales $\rangle^{89}$ ofrece pistas interesantes que pueden ayudarnos a entender mejor la lógica político-militar que sucedió a la independencia de las antiguas colonias hispanoamericanas, entre ellas el Perú. En el contexto imperial, que es de donde surgen las nuevas naciones, la soberanía fue «hecha y deshecha» en innumerables ocasiones. Para entender este proceso, Adelman sugiere romper con

89 Adelman, 2008: 319-340. 
modelos convencionales. Lo que propone, además, es que conectemos la historia de las naciones, es decir, la trayectoria de las nuevas repúblicas, con la de sus complejos orígenes imperiales, donde la guerra ocupó un lugar fundamental. Lo que distingue a los imperios no es una definición absoluta de la soberanía, sino, por el contrario, su apuesta por el pluralismo legal. A la amalgama de una variedad de prácticas institucionales deben añadírsele la indefinición de sus contornos territoriales y un belicismo nunca atemperado. Volver la vista a los orígenes «premodernos» de un vocabulario político que es de estirpe republicana clásica puede permitir analizar las diversas maneras en que el poder estatal y la autonomía fueron combinados para crear ese desequilibrio estructural que define a una soberanía precaria y fluida. Hijos de un ejército imperial, donde sirven y aprenden la lógica y la logística de la guerra, los militares trasladan a la era republicana su visión «desequilibrada» de la política. Luego de la independencia, ellos adoptan el credo republicano, que les resulta —qué duda cabe - de gran utilidad, pero también es innegable que el único modelo político que conocen para llevar adelante su proyecto de gobernar en solitario la república depende del acto de «hacer y deshacer» una soberanía que por definición es plural y diversa.

\section{ARCHIVOS}

Archivo José Gregorio Paredes.

Archivo Domingo Nieto.

Archivo Luis José de Orbegoso.

\section{PERIÓDICOS}

Mercurio Peruano, Lima, 1791-1795.

El Peruano, Lima, 1811.

El Semanario Republicano, Santiago de Chile, 1818.

Los Andes Libres, Lima, 1821.

La Abeja Republicana, Lima, 1822.

El Republicano, 1822, 1845.

El Sol del Perú, Lima, 1822.

El Tribuno de la República, Lima, 1822.

La Cola del Cometa, Santiago de Chile, 1827. 
El Telégrafo de Lima, Lima, 1834-1836.

El Comercio, Lima, 1843.

El Diablo. Periódico Infernal, 1848.

El Zurriago, Lima, 1849.

El Progreso, Lima, 1851.

\section{BIBLIOGRAFÍA}

Adelman, Jeremy, «An Age of Imperial Revolutions», American Historical Review, 113/2 (Chicago, abril de 2008): 319-340.

Aguilar Rivera, José Antonio, En pos de la quimera: reflexiones sobre el experimento constitucional atlántico, México, Centro de Investigación y Docencia Económica/FCE, 2000.

Aguirre, Carlos y McEvoy, Carmen, «Introducción», Carlos Aguirre y Carmen McEvoy (eds.), Intelectuales y poder. Ensayos en torno a la república de las letras en el Perú e Hispanoamérica (ss. XVI-XX), Lima, IFEA/IRA, 2008: 13-43.

Anna, Timothy, La caída del gobierno español en el Perú. El dilema de la independencia, Lima, IEP, 2003.

Appleby, Joyce, Liberalism and Republicanism in the Historical Imagination, Cambridge-Mass, Harvard University Press, 1992.

Basadre, Jorge, La Iniciación de la República, Lima, UNMSM, 2002, 2 ts.

Baylin, Bernard, Ideological Origins of the American Revolution, Cambridge-Mass. The Belknap Press of Harvard University Press, 1967.

Colección Documental de la Independencia del Perú (CDIP), XV, Primer Congreso Constituyente, 3, Lima, Comisión Nacional del Sesquincentenario de la Independencia del Perú, 1971.

Chiaramonte, José Carlos, Nación y Estado en Iberoamérica. El lenguaje político en tiempos de la Independencia, Buenos Aires, Editorial Sudamericana, 2004.

Chiaramonti, Gabriella, Ciudadanía y Representación en el Perú (1808-1860): los itinerarios de la soberanía, Lima, ONPE y Universidad Nacional Mayor de San Marcos, 2005.

Constituciones políticas del Perú. 1821-1919, Lima, Imp. Torres Aguirre, 1922.

Espinosa, Juan, Diccionario para el pueblo, Lima, IRA-PUCP/University of the South-Sewanee, 2001 [1855].

Gargarella, Roberto, «Comentario sobre En pos de la quimera de José Antonio Aguilar», Política y Gobierno, IX/2 (México, 2002): 445-467. 
González Vigil, Francisco de Paula, «Discurso pronunciado por el Dr. [...] en la reunión pública que tuvo lugar en la ciudad de Tacna el día 14 de marzo, con motivo de haberse propuesto por el síndico procurador de la municipalidad que esta provincia se separase de Lima y Arequipa; que se formase un nuevo departamento con los de Moquegua y Tarapacá y se pusiese bajo la inmediata protección del presidente de Bolivia», Documenta. Revista de la Sociedad Peruana de Historia, III/1 (Lima, 1951-1955).

Jamanca Vega, Marco, «El liberalismo peruano y el impacto de las ideas y de los modelos constitucionales a inicios del siglo XIX», Historia Constitucional, 8 (2007): http://hc.rediris.es/08/index.html

Luna Pizarro, Francisco Xavier de, Escritos políticos, Recopilación, introducción y notas de Alberto Tauro, Lima, UNMSM, 1959.

Majluf, Natalia, «Los fabricantes de emblemas. Los símbolos nacionales en la transición republicana. Perú, 1820-1825», Ramón Mujica (ed.), Visión y símbolos. Del virreinato criollo a la república peruana, Lima, Banco de Crédito del Perú, 2006: 203-241.

Martínez Riaza, Ascensión, La prensa doctrinal en la independencia del Perú, 1811 1824, Madrid, Cultura Hispánica, 1985.

McEvoy, Carmen, «El motín de las palabras», Carmen McEvoy, Forjando la nación: Ensayos de historia republicana, Lima, IRA, 1999: 1-60.

McEvoy, Carmen, «Estudio Preliminar», Juan Espinosa, Diccionario para el pueblo, Lima, IRA-PUCP/University of the South-Sewanne, 2001: 21-100.

McEvoy, Carmen, «Seríamos excelentes vasallos y nunca ciudadanos: Prensa republicana y cambio social en Lima, 1791-1822», Iván Jaksic (ed.), The Political Power of the Word: Press and Oratory in Nineteenth-Century Latin America, Londres, Institute of Latin American Studies, 2002: 34-63.

McEvoy, Carmen, «República/Republicanos», Javier Fernández Sebastián (dir.), Diccionario politico y social del mundo iberoamericano, Madrid, Fundación Carolina/Sociedad Estatal de Conmemoraciones Estatales/Centro de Estudios Políticos y Constitucionales, 2009: 1345-1357.

McEvoy, Carmen y Ana María Stuven, «Estudio Preliminar» de La República Peregrina: Hombres de armas y letras en América del Sur, 1800-1884, Lima, Instituto Francés de Estudios Andinos e Instituto de Estudios Peruanos, 2007: 13-30.

McEvoy, Carmen, «Estudio Preliminar», Carmen McEvoy y José Luis Rénique (compilación, estudio preliminar y proemio), Soldados de la República. Guerra, correspondencia y memoria en el Perú (1830-1844), Lima, Fondo Editorial del Congreso del Perú/IRA, 2010, I: 27-81.

McEvoy, Carmen, «De la República jacobina a la República práctica: los dilemas del liberalismo en el Perú, 1822-1872», Iván Jaksic (ed.), Liberalismo y poder: Latinoamérica en el siglo XIX, Santiago de Chile, FCE, 2011a: 207-244. 
McEvoy, Carmen, «La guerra maldita: Domingo Nieto y su tiempo, 1832-1844», 2011b, texto inédito.

McEvoy, Carmen, «La patria científica», Carmen McEvoy, Mauricio Novoa y Elías Palti (eds.), En el nudo del Imperio: Independencia y Democracia en el Perú, Lima, Fondo Editorial del Congreso del Perú, 2011c.

Nieto, Domingo, Memoria de los hechos que justifican la conducta política que como general del Ejército del Perú ha tenido [...] en la época que comprenden los años del 34 al 39, y muy particularmente los que tienen relación a la en que se proclamaron los pueblos contra la Confederación, Lima, Imprenta de El Comercio, 1839.

Pacheco Vélez, César, «José Gregorio Paredes y el patriotismo republicano» [manúscrito inédito].

Palti, Elías, El tiempo de la política: el siglo XIX reconsiderado, Buenos Aires, Siglo XXI, 2007.

Paredes, José Gregorio, Lecciones de Matemáticas. Tomo I. Que comprehende la aritmética y la introducción al Algebra por el D.D. [...] Catedrático de prima de dicha facultad en la universidad de San Marcos, cosmógrafo mayor del Perú y miembro de la Sociedad Patriótica de Lima, Lima, Imprenta del Estado, 1822.

Peralta, Víctor, La independencia y la cultura política peruana (1808-1821), Lima, IEP Fundación M.J. Bustamante de la Fuente, 2010.

Pocock, J. G. A., The Machiavellian Moment: Florentine Thought and the Atlantic Republican Tradition, New Jersey, Princeton, 1975.

Pocock, J. G. A., Virtue, Commerce and History: Essays on Political Thought and History, Chiefly in the XVIIIth Century, Cambridge, Cambridge University Press, 1985.

Puente Candamo, José Agustín de la, Antología de la Independencia, Lima, Comisión Nacional del Sesquincentenario de la Independencia del Perú, 1974.

Rama, Ángel, La ciudad letrada, Hannover, Ediciones del Norte, 1984.

Rivera, Víctor Samuel, «Liberalismo», Javier Fernández Sebastián (dir.), Diccionario político y social del mundo iberoamericano, Madrid, Fundación Carolina/Sociedad Estatal de Conmemoraciones Estatales/Centro de Estudios Políticos y Constitucionales, 2009: 808-823.

Sabato, Hilda, «La reacción de América: la construcción de las repúblicas en el siglo XIX», en Roger Chartier y Antonio Ferros (comps.), Europa, América y el mundo: tiempos históricos, Madrid, Marcial Pons, 2006.

Sánchez Carrión, José Faustino, «Carta al editor del Correo Mercantil y Político de Lima. Sobre la inadaptibilidad [sic] del gobierno monárquico al Estado libre del Perú», CDIP, I, Los ideólogos, 9, Lima, Comisión Nacional del Sesquincentenario de la Independencia del Perú, 1974a: [1822]. 
Sánchez Carrión, José Faustino, «Carta remitida sobre la forma de gobierno conveniente al Perú», CDIP, I, Los ideólogos, 9, Lima, Comisión Nacional del Sesquincentenario de la Independencia del Perú, 1974b [1822].

Sánchez Carrión, José Faustino, «Discurso preliminar del proyecto de Constitución de 1823», CDIP, I, Los ideólogos, 9, Lima, Comisión Nacional del Sesquincentenario de la Independencia del Perú, 1974c [1823].

Sánchez Concha, Rafael, «La tradición política y el concepto de "cuerpo de república” en el Virreinato», Tedoro Hampe, (ed.), La tradición clásica en el Perú virreinal, Lima, UNMSM, 1999: 101-114.

Skinner, Quentin, The Foundations of Modern Political Thought. The Age of Reformation, Cambridge, Cambridge University Press, 1988.

Skinner, Quentin, Liberty before Liberalism, Cambridge, Cambridge University Press, 1997.

Skinner, Quentin, Visions of Politics, Cambridge, Cambridge University Press, 2002.

Tauro del Pino, Alberto, «Fundación de la Biblioteca Nacional», Anuario Bibliográfico de la Biblioteca Nacional (Lima, 1951): IX-XII.

Thibaud, Clement, Repúblicas en Armas: Los ejércitos bolivarianos en la Guerra de la Independencia en Colombia y Venezuela, Lima y Bogotá, Instituto Francés de Estudios Andinos y Planeta, 2003.

Thurner, Mark, From Two Republics to One Divided: Contradictions of Postcolonial Nationmaking in Andean Peru, Durham y Londres, Duke University Press, 1997.

Unanue, Hipólito, CDIP, I, Los ideólogos, 8, Lima, Comisión Nacional del Sesquincentenario de la Independencia del Perú, 1974.

Varela Suanzes, Joaquín, «El liberalismo francés después de Napoleón. De la anglofobia a la anglofilia», Revista de Estudios Políticos, 76 (Madrid, 1992): 29-43.

Vidaurre, Manuel Lorenzo de, «Discurso a los habitantes del Perú», CDIP, I, Los ideólogos, 5, Lima, Comisión Nacional del Sesquincentenario de la Independencia del Perú, 1971a: 360-368.

Vidaurre, Manuel Lorenzo de, «Discurso que pronunció el Dr. D. Manuel Lorenzo Vidaurre y Encalada, Presidente de la Corte de Justicia, el día de su instalación. Truji1lo, 1824», CDIP, I, Los ideólogos, 5, Lima, Comisión Nacional del Sesquincentenario de la Independencia del Perú, 1971b [1824]: 355-359.

Vidaurre, Manuel Lorenzo de, «Discurso quinto: leyes fundamentales que convienen al Perú. Trujillo, 1824», CDIP, I, Los ideólogos, 5, Lima, Comisión Nacional del Sesquincentenario de la Independencia del Perú, 1974c [1824]: 369-381.

Vidaurre, Manuel Lorenzo de, «Discurso sexto: continúan las leyes fundamentales que convienen al Perú. Cualesquiera que sea la alteración que sufra la Constitución del Perú, la forma republicana no ha de variar. Trujillo, 1824», CDIP, I, Los ideólo- 
gos, 5, Lima, Comisión Nacional del Sesquincentenario de la Independencia del Perú, 1971d [1824]: 382-398.

Vidaurre, Manuel Lorenzo de, «Discurso séptimo: continúan las leyes fundamentales, rentas. Los ciudadanos están obligados a sostener al Estado y el Estado a facilitar los medios con los cuales los ciudadanos los sostengan. Trujillo, 1824», CDIP, I, Los ideólogos, 5, Lima, Comisión Nacional del Sesquincentenario de la Independencia del Perú, 1971e [1824]: 399-420.

Vidaurre, Manuel Lorenzo de, «Entretenimiento 3», CDIP, I, Los ideólogos, 5, Lima, Comisión Nacional del Sesquincentenario de la Independencia del Perú, 1971f: 178-180.

Vidaurre, Manuel Lorenzo de, Cartas americanas, Lima, Comisión Nacional del Sesquincentenario de la Independencia del Perú, 1973.

Wood, Gordon, The Creation of the American Republic, 1776-178, Chapel Hill, University of North Carolina Press, 1969.

Fecha de recepción: 24 de marzo de 2011

Fecha de aceptación: 25 de julio de 2011

\section{Not one republic but many: a study of the theoretical bases of Peruvian republicanism, 1821-1834}

The article seeks to explore three strands of Peruvian republicanism between 1821 and 1834. One of these was the "patria cientifica» [scientific homeland] which flourished within the heart of the Sociedad Patriótica de Lima. This was represented by a group of scientific men, headed by Hipólito Unanue and among whom José Gregorio Paredes played a leading role. The second strand was of a legal-philosophical character due to its emphasis on concepts like freedom and sovereignty, and was forged in discussions over the possibility of either a constitutional monarchy or a strictly republican regime whose main spokesman was the Trujillo lawyer José Faustino Sánchez Carrión. Militarized republicanism, the third category of thought discussed in this article, arose as a response to the problem of the war against the Spanish empire and was the brainchild of soldiers of the Republic like Domingo Nieto.

Key words: Peru; independence; political culture; Republicanism; "patria científica»; militarized Republicanism. 